\title{
obituary
}

\section{James Craigie}

Professor James Craigie, O.B.E. F.R.S., distinguished for his wide research in bacteriology, died in Edinburgh on 26 August 1978, aged 79.

He was born in 1899 and educated in Perth and at the University of St. Andrew's, where he qualified M.B., Ch.B. in 1923, and later Ph.D. and D.P.H. He was appointed assistant in bacteriology at the University in 1927. In 1931 he moved to the Connaught laboratories, University of Toronto, first as research associate, later as lecturer in epidemiology and, in 1946, Professor of Virus Infections. He returned to Britain in 1947 to join the staff of the Imperial Cancer Research Fund.

Craigie's introduction to microbiology was in the laboratories of St. Andrew's University under Professor W. J. Tulloch. Here he carried out work on the serology of typhoid and, with Tulloch, worked and published on the 'flocculation' reaction which occurred when vaccine lymph was mixed with vaccinia-immune serum. He continued these studies when he moved to Canada.

He showed that the 'flocculation' was due to a combination of agglutination of virus particles and precipitation of a soluble substance. Further studies with $F$. O. Wishart revealed that the precipitable substance consisted of two elements, one heat-labile (L), the other heat-stable (S). By ingenious techniques, separate antibodies against the $\mathrm{L}$ and $\mathrm{S}$ fractions were obtained; it became clear that a complex antigen (LS) containing both substances was present on the surface of the virus particle.

Following work over several years on the antigenic properties of typhoid bacilli, his most important contribution to knowledge was his work on typhoid bacteriophages. With K. F. Brandon he described in 1936 a phage specific for strains of $B$. typhosus (now called Salmonella typhi) containing what he described as Vi-agglutinogen. With C. H. Chen in 1938 he found other typhoid phages divisible into four types according to a range of properties. One of these (Type 2) developed a high selective lytic activity for the strain of $B$. typhosus on which it was propagated. Its activity could be regularly modified by changing the strain on which it was grown. With this research tool they found that typhoid bacilli could be divided into a number of types (24 were known by 1947). Strains which could be related on epidemiological grounds all fell into a single type. Here, then, was a method of great value in epidemiology, whereby evidence could be obtained as to whether individual infections could or could not be traced to a common source. The finding has had wide repercussions, for similar methods have been applied to the differentiation of strains of various salmonellas and other organisms.

During the Second World War Craigie was one of a number of workers concerned in developing a vaccine against epidemic typhus, and he also studied the serological relations of epidemic and murine typhus. $\mathrm{He}$ was a member of a joint United StatesCanadian Commission which organised work on protection against rinderpest; it was feared that the enemy might try to introduce the disease into North America.

In 1946, W. E. Gye, the Director of the Imperial Cancer Research Fund, was touring North America to learn of developments in the cancer field, and Craigie accompanied him. Gye then persuaded him to return to Britain to the Fund's Iaboratories at Mill Hill with a view to becoming Director; this he did, succeeding Gye in 1949

Gye, always a passionate believer in the virus theory of cancer held that the survival of mammalian tumour cells after freezing or drying indicated that cellular survival could be ruled out, and that a virus must be concerned. Craigie, however, showed that in frozen tissues, some particularly resistant cells might survive in a modified, 'paramorphic' state. He designed a very effective tissue mincer, and, more important, a cabinet for preserving transmissible tumours at $-70^{\circ} \mathrm{C}$. As a result, numerous propagable tumours, especially those of mice, could be preserved for years; no longer was it necessary to passage them in vivo at frequent intervals, and much time and money were saved. His last work was on Tyzzer's disease of mice, a very troublesome infection in mouse colonies; he was able to cultivate the causative organism (B. piliformis) in fertile eggs.

Craigie was not really happy as Director, preferring to concentrate on his own research and in 1957 he was allowed to do this, Dr R. J. C. Harris assuming overall responsibility for directing the Mill Hill laboratory.

In 1929 Craigie married Margaret Fotheringham, who predeceased him. $\mathrm{He}$ is survived by two daughters. $\mathrm{He}$ was elected F.R.S., Canada, in 1946 and F.R.S., London, in the following year.

He will be especially remembered for the leading role he played in Canadian microbiological research, especially in the years before and during the war, when work on viruses was developing so rapidly.

C. H. Andrewes

\section{Harold Fletcher}

Dr Harold Roy Fletcher, Queen's Botanist in Scotland, Regius Keeper of the Royal Botanic Garden, Edinburgh, from 1956 to 1970 died in Edinburgh on 27 August 1978. Born in Glossop, Derbyshire, he studied under Professors Weiss and Lang in Manchester and then moved to the Department of Botany of the University of Aberdeen as assistant to Professor Craib.

In Aberdeen his first responsibilityto his later amusement-was to teach plant physiology, but he soon turned to his main scientific interest, plant taxonomy and gained a PhD in 1933 for work on the Verbenaceae of Siam. At the same time he had a taste of plant collecting in the Faroes and Iceland and experience of the montane flora of Scotland for which he had an abiding affection.

In 1934 he moved to the Royal Botanic Garden, Edinburgh, then under the direction of Sir Willian Wright Smith and continued work on Asiatic floras gaining a DSc from Edinburgh University in 1939. Then followed a most rewarding period working on the rich collections of Chinese plants including a monograph of the genus Primula in collaboration with Sir William. At the same time he taught many university courses in botany, especially a course in taxonomy, which in its modern synthetic approach had no equal in Britain. Several strong modern currents in plant taxonomy in Britain flowered from these lectures.

During the years 1951-54 he turned his attention to horticulture-he had a rare eye for 'a good plant'-as Director the Royal Horticultural Society's Garden at Wisley in Surrey. And from this stemmed his activity in horticultural nomenclature as secretary for ten years of the International Commission for Horticultural Nomenclature 